\title{
PENGARUH MODEL PEMBELAJARAN LEARNING STARTS WITH A QUESTION TERHADAP HASIL BELAJAR MATEMATIKA SISWA PADA MATERI MATRIKS KELAS X SMK SPP NEGERI ASAHAN TAHUN AJARAN 2018/2019
}

\author{
Agus Muliana ${ }^{1}$, Irwan $^{2}$ \\ STKIP Budidaya Binjai
}

\begin{abstract}
ABSTRAK
Tujuan penelitian ini adalah untuk mengetahui pengaruh model pembelajaran Learning StartsWith A Question terhadap hasil belajar matematika siswa pada materi Matriks di kelas X SMKSPP Negeri Asahan. Populasi penelitian ini adalah semua siswa kelas X SMK-SPP Negeri Asahan. Sedangkan yang menjadi sampel dalam penelitian ini ada dua kelas, yaitu kelas X TPH dan X BUN A. Banyak siswa untuk masing-masing kelas adalah 34 siswa, Instrumen dalam penelitian ini terdiri dari tes uraian sebanyak 5 soal. Dari hasil uji coba validitas, reabilitas, tingkat kesukaran dan daya pembeda soal. Dari hasil uji coba tes ternyata diperoleh sebanyak 5 soal tes valid. Sebelum pengujian hipotesis, terlebih dahulu diuji normalitas dan homogenitas. Dari pengujian diperoleh bahwa sampel berasal dari populasi yang memiliki varians yang homogen dan berdistribusi normal. Dari analisis data rata-rata dan simpangan baku pada kelas eksperimen untuk data pretes 46,471 dan 10,281, sedangkan untuk pretes kelas kontrol 43,059 dan 10,790. Dan dari data rata-rata dan simpangan baku postes 74 dan 10,708 sedangkan rata-rata dan simpangan baku postes kelas kontrol 66,471 dan 10,329. Dari analisis data dengan menggunakan uji $-\mathrm{t}$ pada taraf $\alpha=0,05$ diperoleh $t_{\text {hitung }}=2,951$ sedangkan $t_{\text {tabel }} 1,668$ ternyata $\mathrm{t}_{\text {hitung }}>\mathrm{t}_{\text {tabel }}$ maka $\mathrm{H}_{\mathrm{O}}$ ditolak dan $\mathrm{H}_{\mathrm{a}}$ diterima. Dengan demikian diperoleh kesimpulan bahwa hasil belajar menggunakan pembelajaran Learning StartsWith A Question lebih baik dari pada pembelajaran konvensional pada kelas X SMK-SPP Negeri Asahan.
\end{abstract}

Kata Kunci : Model Pembelajaran Learning Starts With A Question, Matriks 


\section{PENDAHULUAN}

\section{Latar Belakang Masalah}

Dalam kehidupan sehari-hari, matematika berperan sangat besar. Besarnya peran matematika tersebut menuntut siswa harus mampu menguasai pelajaran matematika. Mata pelajaran matematika perlu diberikan kepada semua peserta didik dimulai dari sekolah dasar hingga sekolah menengah untuk membekali peserta didik dengan kemampuan berpikir logis, analisis, sistematis, kritis, dan kreatif, serta kemampuan berbijaksana. Kompetensi tersebut diperlukan agar peserta didik dapat memiliki kemampuan memperoleh, mengolah, dan memanfaatkan informasi untuk bertahan hidup pada keadaan yang selalu berubah, tidak pasti,dan kompetitif.

Namun kenyataannya didapati siswa yang merasa takut atau benci pada pelajaran matematika. Mereka beranggapan bahwa matematika merupakan suatu pelajaran yang rumit dan menakutkan, tanpa menyadari betapa pentingnya pelajaran matematika pada diri mereka. Ada beberapa faktor yang mempengaruhi siswa membenci pelajaran matematika.Diantaranya adalah faktor yang datang dari dalam diri siswa atau yang sering disebut dengan faktor internal, yaitu persepsi siswa pada pembelajaran matematika. Persepsi negatif siswa pada pembelajaran matematika biasanya dipengaruhi oleh masalalu siswa pada matematika. Seperti tidak adanya motivasi yang diberikan oleh guru pada saat dibangku SD atau SLTP, atau ketidaktahuan siswa tentang besernya aplikasi pelajaran matematika pada kehidupan seharihari. Tanpa disadari oleh siswa tersebut, sikapnya membuat persepsi negatif pada pelajaran matematika. Persepsi negatif tersebut melemahkan kemampuannya pada mata pelajaran matematika. Karena siswa tersebut beranggapan bahwa matematika adalah pelajaran yang harus dihindari. Dengan lemahnya kemampuan pada pelajaran matematika, maka secara otomatis hasil belajar matematika siswa tersebut juga akan jelek. Dan faktor eksternal yaitu faktor yang berasal dari luar individu atau diri siswa juga salah satu penyebab rendahnya hasil belajar siswa.

Bebarapa ahli pendidik matematika mensinyalir kelemahan matematika pada siswa indonesia karena pelajaran matematika disekolah ditakuti bahkan dibenci siswa. Hal tersebut karena siswa menganggap matematika merupakan pelajaran yang sangat sulit sehingga menimbulkan kebencian pada matematika. Salah satu penyebab kesulitan belajar siswa adalah kurangnya pemahaman siswa terhadap materi yang akan dipelajari. Hal tersebut disebabkan karena strategi pembelajaran yang dilaksanakan oleh guru yang masih bersifat tradisional, yaitu siswa masih diperlakukan sebagai objek belajar dan guru lebih dominan berperan dalam pembelajaran dengan memberikan konsepkonsep atau prosedur-prosedur baku, sehingga pada pembelajaran ini hanya terjadi komunikasi satu arah.

Dalam pembelajaran metematika pembelajaran yang banyak melibatkan siswa aktif dalam belajar baik secara mental fisik maupun sosial seinggga memberikan pengalaman bagi siswa. Siswa akan belajar lebih baik jika lingkungan diciptakan alamiah. Proses pembelajaran berlangsung alamiah dalam bentuk kegiatan siswa mampu atau mau bertannya pada guru tentang apa yang mereka belum paham pada materi yang disampaikan guru. 
Guru merupakan salah satu penentu dalam pendidikan, sebab secara langsung berupaya mempengaruhi, membina dan mengembangkan kemampuan siswa agar menjadi manusia yang cerdas, terampil dan bermoral tinggi. Sebagai penentu, guru dituntut memiliki kemampuan sebagai pendidik dan pengajar.

Guru matematika yang berhasil adalah guru yang mampu mengatasi dan menyelesaikan masalah pembelajaran dikelas secara bijaksana. Sehubungan dengan itu, tentulah tidak mencukupi bagi seorang guru matematika hanya bergantung pada strategi dan teknik yang lama dalam mengajar matematika,tetapi harus dengan cara yang lain dapat menarik siswa untuk berpartisipasi secara aktif baik fisik, mental maupun emosi. Keberhasilan proses pembelajaran merupakan hal utama yang didambakan dalam melaksanakan pendidikan disekolah. Dalam pembelajaran komponen utama adalah guru dan siswa.

Dalam pembelajaran seringkali dijumpai adanya kecenderungan siswa yang tidak mau bertanya kepada guru meskipun mereka sebenarnya belum mengerti tentang materi yang disampaikan guru. Masalah ini membuat hubungan antara guru dan siswa menjadi pasif sehingga tidak terjadi umpan balik, siswa hanya diam dalam menerima penyampaian materi pembelajaran dari guru. Agar dalam pelaksanaan pembelajaran matematika tidak membosankan sihingga siswa senang dalam pelajaran matematika maka dalam pelaksanaanya dapat menerapkan berbagai strategi. Salah satunya adalah melalui penggunaan model pembelajaran yang tepat dalam proses belajar mengajar.

Hal yang sama juga dinyatakan oleh Sitepu (2019),'Setiap materi pelajaran tentu memiliki tingkat kesukaran yang bervariasi.
Pada satu sisi ada bahan pelajaran yang tidak memerlukan alat bantu, tetapi di lain pihak ada bahan pelajaran yang sangat memerlukan alat bantu media pengajaran seperi gambar, charta, dan sebagainya. Bahan pelajaran dengan tingkat kesukaran yang tinggi tentu sukar diproses oleh siswa. Apalagi bagi siswa yang kurang menyukai bahan pelajaran yang disampaikan itu. Pastilah siswa akan cepat merasa bosan dan lelah. Mereka hanya akan mengkhayal dan berandai- andai saat melihat papan tulis yang dihiasi kapur dan guru yang hanya memberikan ceramah kepada mereka. Hal ini sudah pasti dapat mempengaruhi prestasi belajar siswa. Namun, pada kenyataannya sekarang ini masih banyak guru yang belum menggunakan media audiovisual sebagai alat bantu dan sumber belajar."

Bertitik tolak dari permasalahan di atas, maka peneliti tertarik untuk mengadakan penelitian dalam pengajaran matematika menggunakan model Pembalajaran Learning Starts With A Question. Dalam peroses pembalajaran, siswa dituntut untuk berani bertannya tentang materi yang meraka belum paham. Model Pembalajaran Learning Starts With A Question akan mendorong guru dan siswa melaksanakan pembelajaran secara aktif dan kreatif sehingga diharapkan tercapainya peningkatan hasil belajar secara optimal.

Dengan menggunakan model pembelajaran ini diharapkan guru dan siswa dapat melaksanakan proses pembelajaran dengan tepat, siswa dapat memahami mata pelajaran yang disampaikan oleh guru dan dapat meningkatkan hasil belajar siswa.

Dari uraian diatas, maka peneliti tertarik untuk melaksanakan penelitian dengan judul : “ Pengaruh Model Pembelajaran Learning Starts With A Question Terhadap Hasil Belajar Matematika 
Siswa Pada Materi Matriks Kelas X SMKSPP Negeri Asahan Tahun Ajaran 2018/2019".

\section{Tujuan Penilaian}

Tujuan penelitian merupakan suatu pedoman kegiatan penelitian untuk dapat sampai pada sasaran yang diharapkan. adapun tujuan dilaksanakan penelitian ini adalah untuk mengetahui pengaruh model pembelajaran Learning Starts With A Question pada materi matriks di kelas X SMK-SPP Negeri Asahan 2018/2019.

\section{Manfaat Penelitian}

Manfaat yang ingin dicapai dalam penelitian ini diantaranya adalah sebagai berikut:

1. Bagi guru :

Dapat mengatahui pendekatan pembelajaran yang dapat memperbaiki dan meningkatkan hasil belajar siswa.

2. Bagi siswa :

Bahan masukan agar siswa dapat berpikir kritis dan berani untuk bertanya pada guru tentang materi yang belum di pahami.

3. Bagi sekolah :

Penelitian ini dapat membantu meningkatkan kualitas hasil belajar, khususnya pelajaran matematika, sehingga secara langsung dapat meningkatkan kualitas pendidikan sekolah.

\section{Hipotesis Penelitian}

Hipotesis penelitian ini adalah "model pembelajaran Learning Starts With A Question dapat mempengaruhi hasil belajar matematika siswa pada materi matriks di kelas X SMK-SPP Negeri Asahan Tahun Ajaran 2018-2019"

\section{METODE DAN BAHASAN}

Penelitian ini sudah dilaksanakan di SMK-SPP N Asahan Tahun Ajaran 2018/2019. Populasi pada penelitian ini adalah seluruh siswa kelas X SMK-SPP Negeri Asahan yang terdiri dari tiga kelas yang masing-masing memiliki 34 siswa. Sampel yang digunakan dalam penelitian ini berjumlah dua kelas yang diambil dari tiga kelas. Penelitian kelas eksperimen dan kelas kontrol.

\section{Variabel Penelitian}

variabel penelitian ini yang menjadi variabel bebasnya yaitu model Pembalajaran, sedangkan variabel terkaitnya yaitu hasil belajar matematika siswa dan variabel kontrolnya yaitu potensi guru, materi yang diberikan, lama siswa belajar dan kemampuan awal siswa.

\section{Jenis Penelitian}

Jenis penelitian ini merupakan penelitian quasi ekspermen, sehingga diperlukan dua kelas penelitian yang terdiri satu kelas eksperimen dan satu kelas kontrol. Bagan digambarkan sebagai berikut:

\begin{tabular}{lccc}
\hline Kelompok & Pretes & Perlakuan & Postes \\
\hline Eksperimen & $T_{1}$ & $X_{1}$ & $T_{2}$ \\
\hline Kontrol & $T_{1}$ & $X_{2}$ & $T_{2}$ \\
\hline Desain Penelitian & & \\
Menurut Sugiyono (2014:89) desain \\
yang digunakan dalam penelitian ini adalah \\
desain eksperimen dengan kelompok pretes \\
dan postest.
\end{tabular}

\section{Instrumen Penelitian}

Untuk memperoleh data dan gambaran yang sebenarnya mengenai topik penelitian ini maka peneliti menggunakan alat ukur pengumpulan data adalah tes matematika pokok bahasan matriks. Bentuk teks yang dipilih adalah uraian sebanyak 5 soal. 
Adapaun langkah-langkah yang dilakukan peneliti dalam menyusun tes yaitu :

1. Menentukan ruang lingkup tesdengan materi yang dites adalah matriks di kelas X SMK.

2. Menentukan tingkatan kognitif yang akan diukur.

Tingkatan kognitif yang akan diukur.dalam penelitian ini adalah ingatan $\left(\mathrm{C}_{1}\right)$, Pemahaman $\left(\mathrm{C}_{2}\right)$, dan aplikasi $\left(\mathrm{C}_{3}\right)$.

\section{HASIL DAN PEMBAHASAN Hasil}

Penelitian ini merupakan penelitian quasi eksperimen yang melibatkan dua kelas yang diberi perlakuan yang berbeda, yaitu kelas eksperimen diberikan perlakuan dengan model pembelajaran learning start whit a question dan kelas kontrol dengan pembelajaran konvensional. Penelitian kelas dilakukan secara cluster random sampling dengan jumlah populasi sebanyak 3 kelas dengan jumlah 103 siswa dan yang menjadi sampel adalah kelas X-TPH sebagai kelas eksperimen sebanyaj 34 siswa dan kelas XBUN A sebagai kelas kontrol sebanyak 34 siswa di sekolah SMK-SPP N ASAHAN.

Pada kelas eksperimen sebelum memulai pembelajaran terlebih dahulu guru memberikan setimulasi menggunakan buku atau bahan bacaan kepada siswa dengan tujuan untuk mengetahui sejauh mana taraf pengetahuan siswa mengenai materi yang akan disajikan. Pada kelas kontrol tidak diberikan stimulasi buku atau bahan bacaan melainkan metode yang disampaikan dengan metode ceramah.

Setelah seluruh materi disampaikan pada dua kelas dilakukan tes yang sama untuk mengetahui perbedaan kemampuan antara dua kelas. Dari tes yang dilakukan diperoleh hasil belajar siswa untuk kelas eksperimen nilai tertinggi adalah 88 dan nilai terendah 56, dengan rata-rata 74 dan simpangan baku 10,708 (tercantum pada lampiran), sedangkan kelas kontrol diperoleh nilai tertinggi 80 dan nilai terendah 48 dengan rata-rata 66,47 dan simpangan baku 10,329 (tercantum pada lampiran).

Dari nilai rata-rata dan simpanan baku diatas, diketahui ada perbedaan kemampuan antara kelas eksperimen dan kelas kontrol sehingga dapat disimpulkan bahwa siswa kelas eksperimen lebih aktif dan mampu menyelesaikan soal-soal latihan dibandingkan siswa kelas kontrol.

\section{Pembahasan}

Hasil analisis data postes maka diambil kesimpulan bahwa hasil belajar matematika siswa yang di ajar dengan menggunakan model pembelajaran learning stats whit a question lebih baik dari hasil belajar matematika siswa yang diajar dengan menggunakan metode caramah pada materi matriks. Penelitian ini menemukan bahwa rata-rata hasil postes kelas eksperimen adalah 74 dan kelas kontrol adalah 66,471.

\section{KESIMPULAN DAN SARAN Kesimpulan}

Dari analisis hasil penelitian diperoleh kesimpulan bahwa : Ada pengaruh model pembelajaran learning stats whit a question terhadap hasil belajar matematika siswa pada materi matriks kelas X SMK-SPP Negeri Asahan tahun ajaran 2018/2019”.

\section{Saran}

Berdasarkan hasil penelitian dan simpulan, peneliti mengemukakan saran sabagai berikut:

1. Kepada peneliti selanjut, pada aktivitas perlu ditingkatkan 
berdasarkan deskriptor- deskriptor yang ada.

2. Kepada peneliti selanjutnya pada proses kegiatan belajar mengajar sinteks sangat perlu dimaksimumkan.

3. Mengingat kelemahan peneliti dalam penyusunan soal maka disarankan agar menyusun soal yang lebih baik sesuai taksonomi bloom.

\section{Daftar Pustaka}

Arikunto. 2012. Dasar-Dasar EVALUASI PENDIDIKAN. Jakarta: Bumi Aksara.

Arikunto. 2010. Prosedur Penelitian. Jakarta: PT Rineka Cipta.

Istarani. 2011. 58 Model Pembelajaran Inovatif. Medan: Media Persada.

Nazir. 2011. Metode Penelitian. Bogor: Ghalia Indonesia.
Selameto.2010. Belajar dan Fakto-Faktr Yang Mempengaruhi. Jakarta: Rineka Cipta.

Sitepu, D.R 2019. Perbandingan Hasil Belajar Siswa Dengan Menggunakan Media Audiovisual Dan Tanpa Media Audiovisual Pada Materi Struktur Dan Fungsi Sel Sebagai Unit Terkecil Kehidupan Di Kelas Xi SMA Swasta Esa Prakarsa T.A 2018/2019. J. Serunai Ilmiah Ilmu Pendidikan. Vol 5 No. 1 eISSN: 2621-2676, Hal 11-18

Sudjana. N.2009. Penilaian Hasil Belajar Mengajar. Bandung: PT. Remaja Rosda Karya.

Sugiyono. 2014. Metode Penelitian Administrasi. Bandung: Alfabeta.

Trianto.2011. Mendesain Model Pembelajaran Inovatif-Progresif. Jakarta: Prenada Media Group. 